\title{
鼻腔原発の小細胞癌の一例
}

\author{
池田 拓生・斎藤 等・真鍋 恭弘・本多 徳行 \\ 大坪 俊雄・山田武千代・田中 信之・今村 好章*
}

\section{A Case of Small Cell Carcinoma in the Nasal Cavity}

Takuo Ikeda, Hitoshi Saito, Yasuhiro Manabe, Noriyuki Honda, Toshio Ohtsubo, Takechiyo Yamada, Nobuyuki Tanaka and Yoshiaki Imamura

(Fukui Medical School)

Small cell carcinoma arising in the lung is common, but it also occurs in extrapulmonary sites, although rarely. A case of small cell carcinoma in the nasal cavity of a 56-year-old woman is reported. The patient was treated surgically, followed by irradiation and chemotherapy. However, she died of intracranial invasion of the tumor after 18 months. Histologically, the tumor cells were small, round, and had hyperchromatic nucleus with scanty cytoplasm. Electron microscopic examination revealed neurosecretory granules in the cytoplasm of the neoplastic cells.

Key words: small cell carcinoma, nasal cavity, neurosecretory granules

\section{はじめに}

小細胞癌が肺に発生することはよく知られて いるが，肺以外に発生することは稀であり1), とくに鼻・副鼻腔より発生した小細胞癌はわれ われが検索した限りでは数例の報告が認められ るに過ざない2－7)．今回われわれは鼻腔原発の 小細胞癌の一例を経験したので, カルチノイド 腫瘍と小細胞癌の関連性の考察を加えて報告す る。

\section{症 例}

56歳，女性. 左鼻閉を主訴に1988年10月近医 (耳鼻咽喉科) にて左鼻茸摘出術を施行. 1990 年 1 月再び左鼻閉感出現したため同院受診, 左 鼻腔底腫瘍を指摘され，生検にて悪性腫瘍を疑
われ当科紹介入院となった.

同時期の CT (図 1) にて, 左鼻腔底部に腫 瘍が存在. 胸部 $\mathrm{X}$ 線および $\mathrm{Ga}$ シンチ（図 2 ） にて肺に腫瘍を思わせる所見はなく，Ga シン チにて鼻腔に集積がみられるのみで，全身への 異常集積は認められなかった.

1990年 3 月 22 日, 拡大デンケル法に準じて左 下甲介を含む鼻腔側壁切除および腫瘍摘出術施 行. 術後病理組織検査にて, 未分化な腺癌と診 断され, 術後総線量 $50 \mathrm{~Gy}$ の放射線療法を施行 した。局所㧍よび全身状態良好にて，1990年 6 月退院となるも，1990年12月硬口蓋に痛みを訴 え, また両側頸部 (左 : $22 \mathrm{~mm}$, 右 : $35 \mathrm{~mm}$ ) にリンパ節を触れ，局所再発および両側頸部リ 
ソパ節転移にて，1991年 1 月再入院. 1991年 1 月17日全身麻酔下に両側頸部郭清術, および再 発腫瘍摘出術を施行した.

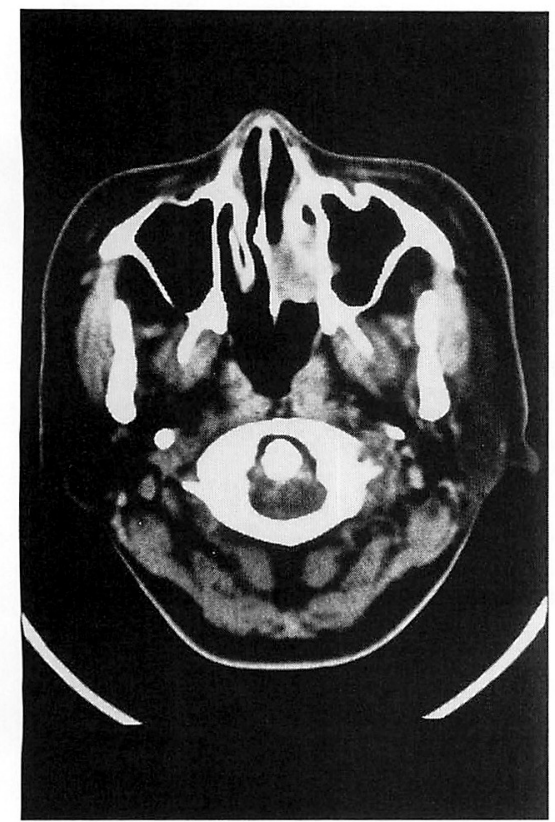

図 1 初揹時の CT 像 左鼻腔底部に腫痬がみられる.
術後摘出標本の $\mathrm{HE}$ 染色（図 3 ）にて，比較 的小型で，添济均一な，核/細胞質比の極めて 高い細胞のびまん性増殖からなり，クロマチン はびまん性に分布し，核小体はめだたず，多数 の分裂像が認められた。 また，管腔形成や角化 は認められず，リボン状配列，索状配列なども みられなかった，免疫組織化学染色にて，ケラ チン, CEA (carcinoembryonic antigen), EMA (epithelal membrane antigen) 陽性. ビメンチ ン陰性にて上皮系腫瘍が疑われ，NSE (neuronspecific enolase) 陽性, LCA (leukocyte common antigen) 陰性, PAS 陰性より, 小細胞癌 が疑われた。ささらに電子顕微鏡による超微形態 学的観察 (図 4 ) にて, 腫瘍細胞の細胞質内に 限界膜で囲まれた直径約 150 200 nm の高電 子密度の神経内分泌顆粒を, また一部の細胞間 にはデスモゾームを認め, 鼻腔原発の小細胞癌 と診断された。な和血中の NSE は高值を示し たが，内分泌異常は認められなかった. 1991年 2 月 1 日よりパラプラチン (総量 $900 \mathrm{mg}$ ), シ スプラチン $(240 \mathrm{mg})$ 执よび VP-16 (1200 mg)に よる多剤併用化学療法を施行した。1991年 5 月 より再び局所および両側頸部りンパ節に再発が

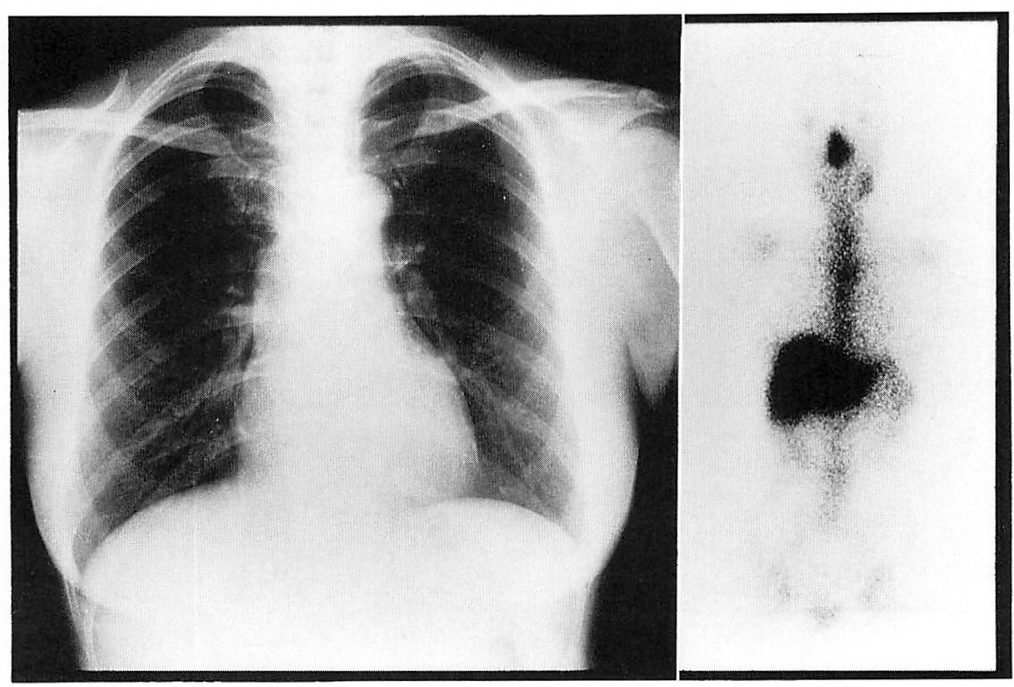

図 2 胸部 $\mathrm{X}$ 線像と $\mathrm{Ga}$ シンチ

胸部に異常なく鼻腔に異常集積がみられる. 


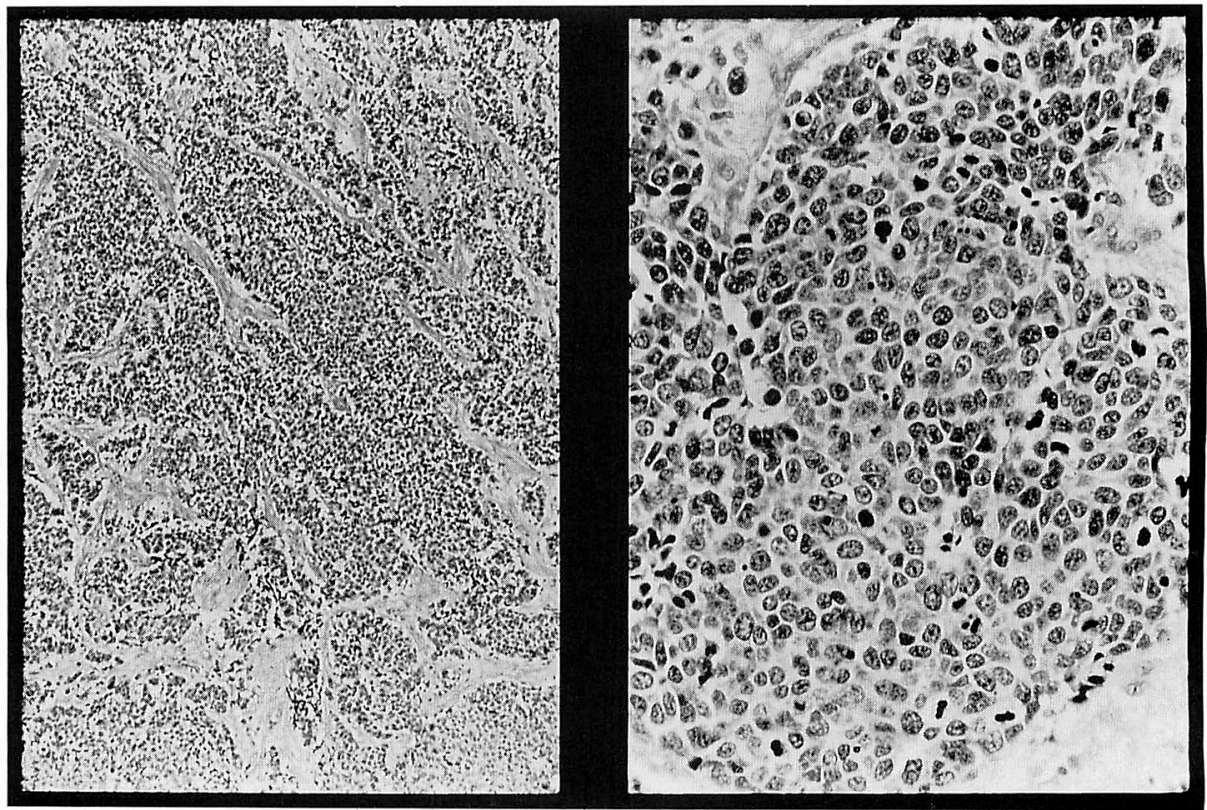

図 3 摘出組織の病理組織像 (HE 染色)

左: 弱拡大 右 : 強拡大

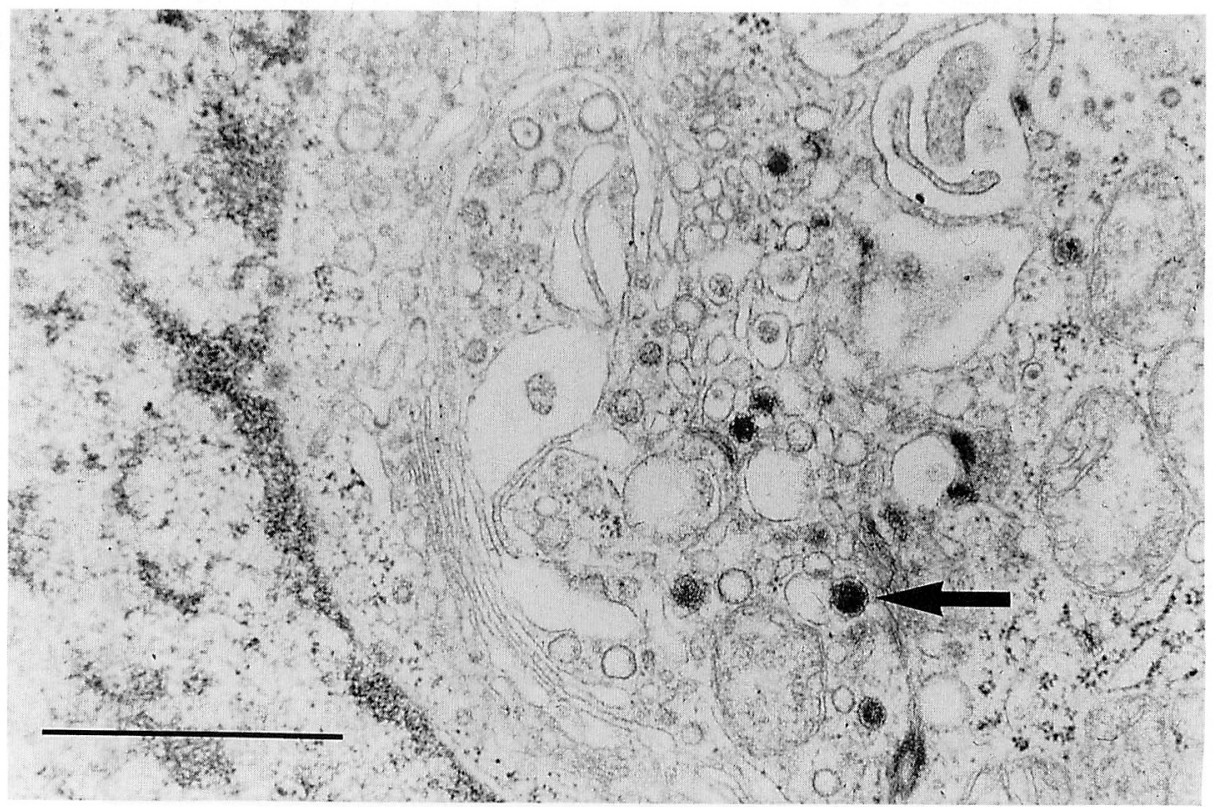

図 4 腫瘍の電子顕微鏡像（スケール $=1 \mu$ ) 細胞質内の神経内分泌顆粒 $(\hookleftarrow)$. 
みられ, さらに THP-ADM (160 mg), VCR (7 $\mathrm{mg}), \mathrm{ACNU}(200 \mathrm{mg})$ 飞て化学療法施行するも 効果なく，1991年 9 月29日腫瘍の頭蓋内浸潤に て死亡した，病理解剖は施行できなかった。

\section{考察}

小細胞癌 (small cell carcinoma) は気管支に 発生する小型の細胞からなる一見未分化な腫瘍 で，詳細に検討すると上皮性の特徵に加えて， 神経内分泌性の形質を兼ね備えている特殊な腫 瘍である8). 一般に小細胞癌は肺に好発するが， 稀に肺以外の藏器にも発生することがあり1), 頭頸部領域では喉頭, 下咽頭, 唾液腺, 鼻・副 鼻腔，気管などの報告がある8 10)。唾液腺は 最も好発しやすい部位の一つであるが1), 鼻・ 副鼻腔, 特に鼻腔より発生した小細胞癌の報告 は稀である2) 5)。一般に内分泌細胞腫瘍はカル チノイドと小細胞癌 (内分泌細胞癌) に分類さ れる．両者は組織学的所見と悪性度が異なるた め明確に区別する必要がある，カルチノイドは 組織学的に比較的広い細胞質と円形〜卵円形の 均一な小型核を有し，核分裂像はないか稀であ り，索状・リボン状配列を示す，発育は緩徐で 低悪性度であることを特徵とする。一方，小細 胞癌の組織学的特徵としては, 細胞は均一に比 較的小型でリンパ球様であり，核・細胞質比が 高く，核はクロマチンに富み，核小体は不明瞭 で，分裂像が多数認められ，索状・リボン状配 列はほとんどみられないことなどがあげられる。 発育は急速で，きわめて予後不良である.今回 の症例は，後者の特徵をほとんどすべて兼ね備 えていた。また，免疫組織学的に NSE が陽性 であり，超微形態学的観察で神経内分泌顆粒が 認められたことから，鼻腔原発の小細胞癌と診 断された。

頭頸部原発の小細胞癌はその発生部位により 予後が大きく異なり, 喉頭, 気管は予後不良で, 鼻・副鼻腔は比較的良好（1 年生存率 $81 \% ， 5$ 年生存率 $71 \%$ ）であるとの報告がある9 。放射 線感受性も高く (57\%), 外科的切除に加光術 後放射線療法拈よび補助的多剤併用化学療法が
有効であるとの報告があるが99，症例も少なく， 病態も不明瞭なことが多くまだ有効な治療法は 確立していない，局所再発し易く，脳などへの 遠隔転移は稀で, 頸部リンパ節が初発であ る319)。 また内分泌異常は稀であると報告され ている2)9.

一方，鼻・副鼻腔などのカルチノイド腫瘍の 報告があるが7)，内分泌腫瘍に属し， apudoma とも呼称されている.このカルチノイドの場合, 産生ホルモンの過剩症状の有無から, 臨床的に 機能性腫瘍と非機能性腫瘍とに区別されるが, 一般的には後者が多い。

また，このカルチノイドの概念は最近大きく 変貌しつつある. 寸なわち, 内分泌腫瘍が悪性 度の面から整理されつつある. 内分泌細胞腫瘍 を当初の臨床病理学的特徴をもつ古典的カルチ ノイドと高異型度で高悪性度の小細胞癌（また は燕麦細胞癌）とに大別する分類法に变わりつ つある11)。したがって, 過去の症例には両者が 混在している可能性があり7)，予後の悪いのは 小細胞癌であり，良いのはカルチノイド腫瘍と も考えられるし，欧米の鼻・副鼻腔小細胞癌の 5 年生存率が $71 \% \%^{9)}$ と良いのも両者が混在して いる可能性がある.

今回のわれわれの症例は悪性度の高い小細胞 癌であり, 腫瘍の頭蓋内進展により不幸な転帰 をとったが, 高悪性度に加えて初発部位が鼻空 底といら機能と形態上拡大切除を躊躇する部位 であったこと, 最初は未分化腺癌と診断された こと, 肺の小細胞癌に有効とされる化学療法も 無効であったこと, 最後は手術不能の頭蓋内進 展をきたしたこと，などが予後不良であった原 因と考えられる。

\section{まとめ}

56歳, 女性の左鼻腔に原発した小細胞癌の一 例を報告した。最初デンケル法に準じ摘出する も, 口蓋部への進展と両側リンパ節転移をきた し, 拡大再手術を施行するも, 頭蓋内進展をき たし, 小細胞癌に有効とされる化学療法を施行 するも効果なく， 1 年 6 力月で鬼籍に入った. 
本論文の要旨は第10回北陸頭頸部腫瘍懇話会にて 口述した。

\section{参考文献}

1) Remick SC, Hafez GR and Carbone PP : Extrapulmonary small cell carcinoma. Medicine $66: 457 \sim 471,1987$.

2) Kameya $T$, Shimosato $Y$, Adachi $I$, et al : Neuroendocrine carcinoma of the paranasal sinus. Cancer $45: 330 \sim 339,1980$.

3) Silva EG, Butler JJ, Mackay B, et al : Neuroblastomas and neuroendocrine carcinomas of the nasal cavity. Cancer $50: 2388$ $\sim 2405,1982$.

4) Rejowski JE, Campanella RS and Block LJ : Small cell carcinoma of the nose and paranasal sinuses. Otolaryngol Head Neck Surg $90: 516$ 517, 1982.

5) Weiss MD, deFries HO, Taxy JB, et al : Primary small cell carcinoma of the paranasal sinuses. Arch Otolaryngol 109 : 341 343, 1983.

6) Soussi AC, Benghiat A, Holgate CS, et al : Neuroendocrine tumours of the head and neck. J Laryngol Otol 104 : 504 507, 1990.

7）鈴木 湛, 山本邦之, 村田雅美: 頭頸部原発力 ルチノイド腫瘍の 5 症例. 耳鼻臨床 $77: 1187$ $\sim 1196,1984$.

8）下里幸雄 : 非定型的カルチノイドと小細胞癌. 病理と臨床 9 増 : 236, 1991.

9) Baugh RF, Wolf GT and Mcclatchey KD : Small cell carcinoma of the head and neck. Head Neck Surg 8 : 343 354, 1986.

10）馬谷克則, 佐藤武男, 吉野邦俊 : 下咽頭小細胞 癌の 2 例. 耳鼻 $35: 860 \sim 864,1989$.

11）岩㴊三哉：カルチノイド腫瘍. 病理と臨床 9 增 : $152,1991$.

$$
\left(\begin{array}{l}
\text { 別刷請求先 : 池田拓生 } \\
\text { 个910-11 福井県吉田郡松岡町下合月23-3) } \\
\text { 福井医科大学耳鼻咽喉科学教室 }
\end{array}\right.
$$

